\title{
Information Orientation, Information Technology Governance, and Information Technology Service Management: A Multi-level Approach for Teaching the MBA Core Information Systems Course
}

\author{
John Beachboard and Kregg Aytes \\ Idaho State University, Pocatello, Idaho, USA \\ beach@isu.edu aytekreg@isu.edu \\ Executive Summary
}

Core MBA IT courses have tended to be survey courses that cover important topics but often do not sufficiently engage students. The result is that many top-ranked MBA programs have not found such courses useful enough to include in their core MBA requirements. In this paper, we present a design of an MBA course emphasizing information technology and intending to be a valuable part of a core MBA program.

The primary audience for this course is the general MBA student, and the primary teaching objectives of the course are for students to (1) recognize that IT plays a vital role in the functioning of most modern organizations, (2) recognize that the effective application of IT requires the active engagement of non-IT as well as IT management, and (3) acquire the tools and concepts necessary for non-IT managers to participate in the effective management of an enterprise's IT resources.

The basic framework by which we accomplish these objectives conceptualizes IT management into three domains of activity: executive-level IT governance, enterprise-level IT governance/management, and functional-level IT governance/management. Executive-level IT governance issues reside at the board and executive level and include parameters involving the strategic application of IT. Enterprise-level IT management/governance includes those activities that are best accomplished through joint business and IT management participation, such as the development of IT service level agreements. These two areas are most emphasized in the course. Functional-level IT management refers to those activities that should be solely the responsibility of IT managers. This framework provides a means for parsing out IT management responsibilities with the intent of emphasizing that some IT management activities require the involvement of non-IT managers.

As a means for helping students understand what an enterprise needs to do well to use IT to support its goals, we applied the Information Orientation framework (Marchand, Kettinger, \& Rol-

Material published as part of this publication, either on-line or in print, is copyrighted by the Informing Science Institute. Permission to make digital or paper copy of part or all of these works for personal or classroom use is granted without fee provided that the copies are not made or distributed for profit or commercial advantage AND that copies 1) bear this notice in full and 2) give the full citation on the first page. It is permissible to abstract these works so long as credit is given. To copy in all other cases or to republish or to post on a server or to redistribute to lists requires specific permission and payment of a fee. Contact Publisher@InformingScience.org to request redistribution permission. lins, 2001). This framework considers how well organizations (1) collect, process and maintain their information (information management practices), (2) share information and use it to support decision making, and (3) employ specific IT management practices. These three domains comprise an organization's "information orientation maturity," which is posited to relate to an or- 
ganization's success. To provide explicit implementation guidance, we delve more deeply into specific actions that managers can take to raise their enterprise's information orientation by synthesizing the topics of IT governance and enterprise architecture as presented by a number of prominent authors. Included at this level are such things as executive-level IT steering committees, the management of IT investments, and the laws, industry standards, and legal and ethical issues involved in enterprise level IT decisions.

We then take the discussion down to the next level and use the concepts of IT service management to convey how managers can align IT services with business needs. The IT Services Management (ITSM) literature (1) emphasizes the design of IT services rather than the specification of business applications and technology, and (2) makes explicit the linkage between IT services and the business processes they are intended to support. An IT service orientation helps make the relationship between IT investment and business value more explicit and offers a vocabulary more easily understood by non-IT management, thus helping to improve communication between IT and the activities it supports.

Finally, to help solidify students' conceptual understanding, the course includes an experiential learning component. We assign a semester-long project where student teams consult with area businesses (or not-for-profit organizations). The assignment calls for the structured application of one of the conceptual frameworks introduced in the course. The students administer structured surveys, perform open-ended interviews, conduct participant observation, and analyze their findings, providing oral and written reports to the client and to the class. We find that students not only benefit from their own efforts but vicariously through the sharing and comparing of experiences with other groups.

MBA students have generally found this course design useful. Pre- and post-course survey data indicate that students better appreciate the roles that non-IT managers play in the effective application of IT resources as a result of the course.

Keywords: MBA Core IS course, information orientation, IT service management, IT governance

\section{Introduction}

"When data for U.S. News \& World Report's twenty top-rated schools was compared, not one school included a stand-alone MIS in the core" (Shore \& Briggs, 2007). The issue, at least for those teaching in the IS discipline, is that apparently these programs have not found sufficient value in IS content to require its inclusion within the core. The issue is not a new one. How do we ensure sufficient value is delivered in a course emphasizing information technology to guarantee its inclusion in the MBA core? Silver, Markus, \& Beath (1995) identified issues with the traditional delivery of IT-related content and recommended the adoption of the Information Technology Interaction Model to be used as a pedagogical framework for identifying, organizing and effectively communicating "what every MBA student needs to know about information systems" (pp. 362-363). The key insight reflected in their model was to apply general systems theory to present information systems in their organizational context rather than focusing directly on the constituent elements of information systems, i.e., the hardware, software, data, people, and procedures.

Apparently, the message did not take. In 2002, 40 distinguished IS faculty were assembled to communicate to AACSB International IS-related knowledge as part of the body of knowledge essential for all undergraduate and graduate business students (Ives et al., 2002). The motivation for their effort was that the Council of the Association for Information Systems draft of the 2002 AACSB accreditation guidelines did not sufficiently "reflect the essential and growing role of 
information systems and technology in the future careers of business school graduates" $(2002, \mathrm{p}$. 467).

Further analysis of core IS offerings occurred in 2003 with the publication of Avison's (2003) analysis of subject-related ISWorld listserv posts. Interestingly, while the Avison ultimately concluded an IS-oriented course should be retained in the MBA core, he did note dissenting opinions expressed by IS faculty. One poster opined that IS courses were "typically NOT well designed... survey courses.... (where) most students are bored to tears..." (2003, p. 121). Not surprisingly, recommendations concerning how core MBA IS courses might be improved continue to be published (Alter, 2006; Aytes \& Beachboard, 2007; Peslak, 2005; Reich, 2000). Yet, as evidenced by Shore and Briggs' (2007) investigation, top-ranked business schools have evidently not found the content compelling enough to merit the inclusion of a dedicated IT-oriented course within their core curricula.

Consistent with the spirit of the Silver, Markus and Beath (1995) paper, we propose a new framework, actually a combination of frameworks, for organizing core MBA IS course material to present what we believe "every MBA needs to know about information systems in organizations" (Ives et al., 2002).

Somewhat tepid reactions to our IS course offering motivated our course redesign effort. While student evaluations of the authors' MBA IS course have been generally positive, the course remained primarily a survey course where lots of "useful" content was presented but did not hang together well. A significant number of students found the IS course content less useful relative to the content received in other classes, with some number each year suggesting that the course be dropped from the core. Over several years, the authors refined the course (evolving toward the course design presented below) but still found too many students were not actively engaging with the material and consequently, not adequately benefiting from the course. The problem appeared to reside less with the cognitive content of the course than with our ability to stimulate affective learning. That is, the course was not helping the students achieve an emotional appreciation of the relevance and practicality of the content.

Consequently, the challenge has been to identify an approach to the course that offers not only relevant and useful content, but a compelling and sustained argument as to why students should care about that content. While our course remains a work in progress, we wish to share what we have learned by:

- Describing our primary objectives in designing this course

- Explaining the logic driving our multi-level approach for presenting business use of information and technology to MBA students, and providing descriptions of the type of material presented within the three primary course modules: information orientation, IT governance, and IT service management

- Explaining our reliance on experiential learning, and

- Reporting student perceptions of the course and outlining our thinking regarding possibilities for future development

It is not our intent to claim the discovery of "new and improved" IT/IS management knowledge. Most, if not all, the content offered in our updated course design has existed for years. Certainly many of the concepts have been refined over time but current IT management concepts are largely consistent with what has come before. To some extent we, as well as the authors upon whom we draw, could be accused of placing old wine in new wineskins. Our belief is that, while the core concepts remain largely consistent with what has come before, vocabulary, focus, and presentation do matter with regard to achieving our affective as well as cognitive learning objectives. 


\section{Course Objectives}

In terms of an overarching goal for our course, we can create no clearer statement than that provided by Silver et al. (1995, p. 363):

.... to increase students' knowledge of the potential benefits, dangers, and limitations of information technology and to equip them with the basic concepts they must apply to leverage the benefits, avoid the dangers, and surmount the limitations.

However, as with most goals, difficulties reside in the details.

We have chosen to design our course to meet the needs of the general MBA student while still providing valuable content for aspiring IT managers. Based on our teaching experience, we have concluded that one source of student discontent has been their perception that we are trying to turn them into IT managers. Our non-IT students have demonstrated little patience when they thought they were being made to learn something they felt should be the responsibility of IT managers. Conversely, aspiring IT managers have legitimately felt that the general purpose approach to IT management often presented in core MBA IS courses poorly or incompletely addressed their needs.

Discussion with our students has led us to agree with Alter's (2006) view that many business managers are too willing to abdicate their responsibilities when it comes to managing the information and technology supporting their business operations. The assumption driving our course design is that general business student motivation can be improved by helping them to distinguish between IT management activities that can be reasonably left the IT professionals and a subset of IT management activities that require the participation of business managers in order to be successfully conducted. In a sense, business managers and business students seem to exploit ambiguity with respect to the identification of IT management roles and responsibilities to avoid dealing with subjects with which they are unfamiliar or uncomfortable. Our primary tasks are to:

1. Help students understand that, while one can argue about whether or not the use of information technology is strategic, they must recognize that information technology certainly plays an important role in the functioning of most modern enterprises.

2. Help students understand that truly efficient and effective application of information technology in the enterprise requires the active engagement of non-IT as well as IT management.

3. Provide tools and concepts intended to promote the productive engagement of non-IT managers in the effective management and control of the enterprise's information and information technology.

Accordingly, the course is intended to address both affective and cognitive learning objectives, encouraging and enabling prospective business managers to take a more proactive role in managing the application of information and technology in support of enterprise goals and objectives.

\section{Course Design}

After much searching we failed to identify an IT management framework that adequately supports our objectives for this course. For example, Luftman (2004) describes an IT management framework where IT processes are broken into levels: strategic, tactical and operational. The framework adopts a time-based perspective where strategic processes have long term impact, tactical processes have short term impact, and operational processes are applied on a day-to-day basis. The COBIT (Control Objectives for Information and related Technology) framework identi- 
fies 34 IT management processes organized in four domains. These are (IT Governance Institute, 2009):

- Plan and organize. Included in this domain are processes for defining a strategic IT plan and direction, defining an information architecture, defining IT processes, managing IT investment, and assessing and managing IT risks.

- Acquire and implement. Included in this domain are processes for identifying automated solutions, acquiring and maintaining applications software and technology infrastructure, procuring IT resources, and managing IT change.

- Deliver and support. Included in this domain are processes for defining and managing service levels, managing third-party services, managing performance and capacity, ensuring systems security, training users, and responding to change requests, service incidents, and systemic problems.

- Monitor and evaluate. Included in this domain are processes for assessing IT processes and internal controls for ensuring regulatory compliance and minimizing IT-related risk, and providing an IT governance framework.

Each of these frameworks has merit depending upon one's purposes. But we find that they blur the IT management responsibilities of IT and non-IT managers. Consequently, we have created an overarching conceptualization of IT management/governance (depicted in Figure 1) that identifies three domains of IT management: executive-level IT governance, enterprise-level IT management/governance and functional-level IT management/governance).

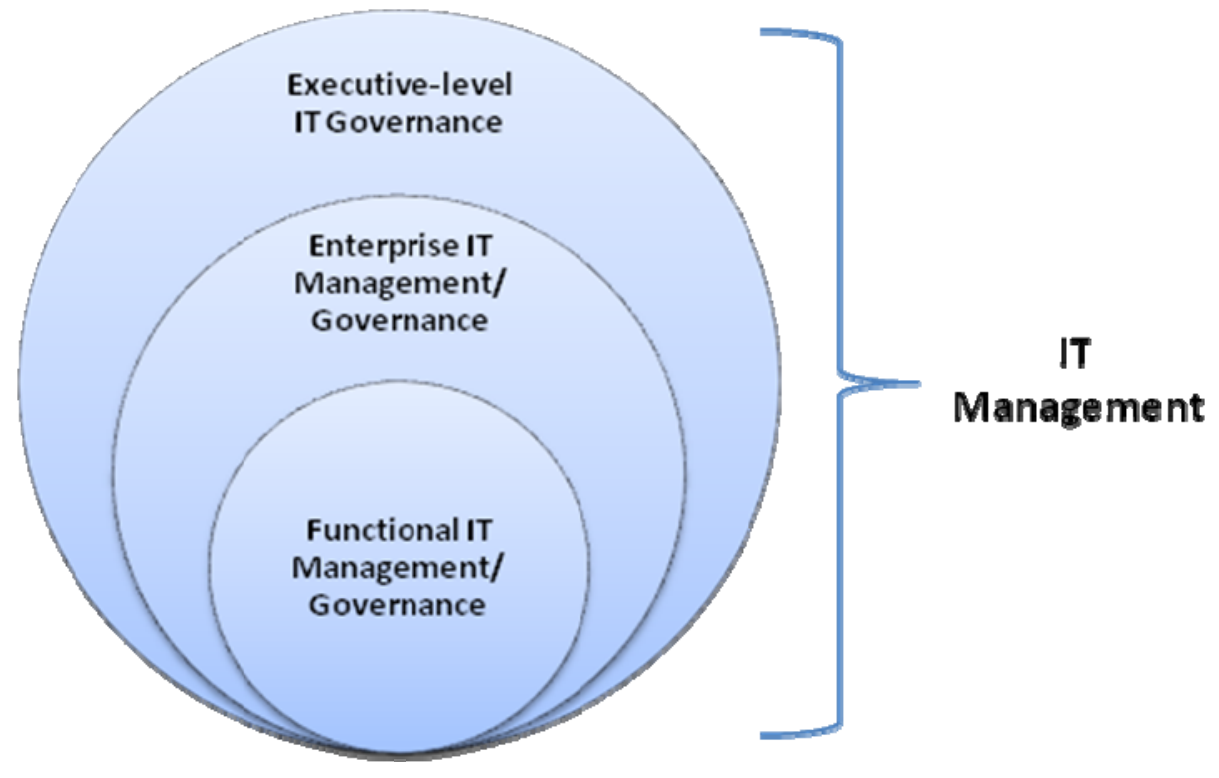

Figure 1. Three Notional Domains of IT Management

Our criteria for determining which IT management activities fall into which domain(s) hangs largely upon the varying levels of engagement or substantive participation by three groups of enterprise managers: board members and executives, business (non-IT) managers, and IT managers. Executive-level IT governance responsibilities reside, not surprisingly, with board/executivelevel managers (which may or may not include an enterprise CIO).

Enterprise-level IT management/governance, using a definition of our own creation, includes ITrelated activities that ideally require joint business and IT management participation. As explained below, we see, for example, the development of IT service level agreements (SLAs) re- 
Information Orientation, IT Governance, and IT Service Management

quiring the active participation of both IT and non-IT managers. If responsibility for developing SLAs is perceived as falling solely on the shoulders of IT managers, the usefulness of such an agreement will likely be undermined.

Functional-level IT management refers to IT-related activities that should be solely the responsibility of IT managers. For example, acceptance testing of new software releases is a technical function best performed and supervised by IT managers (although such a delegation of responsibility need not imply that executives or other non-IT managers should be precluded from ensuring that control mechanisms exist to prevent the fielding of untested software releases). Thus, it is possible that some strategic-level IT management decisions might fall within the domain of functional IT management/governance, e.g., the selection of specific technical standards, while establishing control mechanisms to ensure that effective operational-level functions, e.g., maintenance of configuration management database, might reside within the executive-level IT governance domain.

This framework provides a means for parsing out IT management roles and responsibilities with the intent of emphasizing that some IT management activities require the involvement of non-IT managers. We use this diagram and these definitions in the introduction to the course, emphasizing that the course addresses the two outer circles of the diagram and that they should enroll in our separate IT manager-oriented course if they are interested in learning about the IT management activities relegated to the inner circle.

The next critical issue that we address in our course design concerns selecting an appropriate level or levels of content abstraction. A difficulty that we have found with much of the IT management literature is that IT management prescriptions are provided at such a high level that they are scarcely actionable. We cannot count the number of times we have read admonishments to align IT strategy with business strategy or establish effective relationships among IT and non-IT managers. Certainly, these are valid recommendations, but standing alone, or even taking into consideration the explanations and descriptions offered with these prescriptions, students (and we suspect many practitioners) lack clear ideas about how they might implement those prescriptions.

We suggest that these types of prescriptions are good examples of "know-what" knowledge. They answer the question: What do you need to do to effectively manage IT? What is missing in the literature providing these prescriptions is the "know-how" type of knowledge that provides sufficient detail to guide a manager's actions.

The problematic distinction between knowledge as know-what and knowledge as know-how. Teaching know-how knowledge is difficult and in some cases not achievable in classroom environments. In a sense, know-what represents explicit knowledge while know-how represents implicit knowledge. While teaching, we try to impart explicit knowledge in part by attempting to make some implicit knowledge explicit. Achieving know-how is akin to peeling an onion. Every time a layer of the onion is removed, i.e., some implicit knowledge made explicit, one finds another layer of implicit knowledge is required. One continues removing layers, ultimately reaching a core of tacit knowledge, which by definition cannot be articulated. In the course design described below, we do not mean to imply that we successfully reach the core of the onion. We try to convey several layers of knowledge, as well as provide experiential learning opportunities to introduce some tacit understanding.

Our pedagogical approach is twofold. First, we provide a multi-layered set of theoretical and practice-oriented IT management frameworks. We start at a relatively abstract layer that identifies a comprehensive set of general prescriptions (represented by the Information Orientation (IO) framework). We then peel the onion by introducing management frameworks that provide increasing levels of actionable detail (guidelines for implementing executive-level IT governance, introductions to the IT service strategy and IT service design elements of the IT Infrastructure 
Library (ITIL) framework and finally an introduction to the work systems method developed by Alter (2006). Of course, at every level of actionable detail, the issue of whether sufficient knowhow was provided re-emerges.

Second, we incorporate experience-based learning in the form of student-led IT consulting projects with area businesses or not-for-profit organizations. We emphasize that the conceptual frameworks are best viewed as tools. Knowledge of the tool is different than the knowledge required to effectively use the tool. Consequently, the primary goal of these projects is to help students gain a deeper understanding of the strengths and limitations of frameworks to which they have been introduced and sensitize them to the types of issues where knowledge of the particular organizational contexts is required and judgment and experience must be applied.

Based on the logic outlined above, Figure 2 depicts the high-level concept map governing our course design. In our course introduction and repeatedly throughout the semester, we remind our students that they are taking a course about the business value of IT, not an IT course per se. The key to making this course relevant to MBA students is to stress the connection between IT and the effective operation of the business. We attempt to address the frustrations of aspiring IT managers, at least in part, by advising that while there is more to IT management than will be covered in our course, the content of this course remains important to their needs.

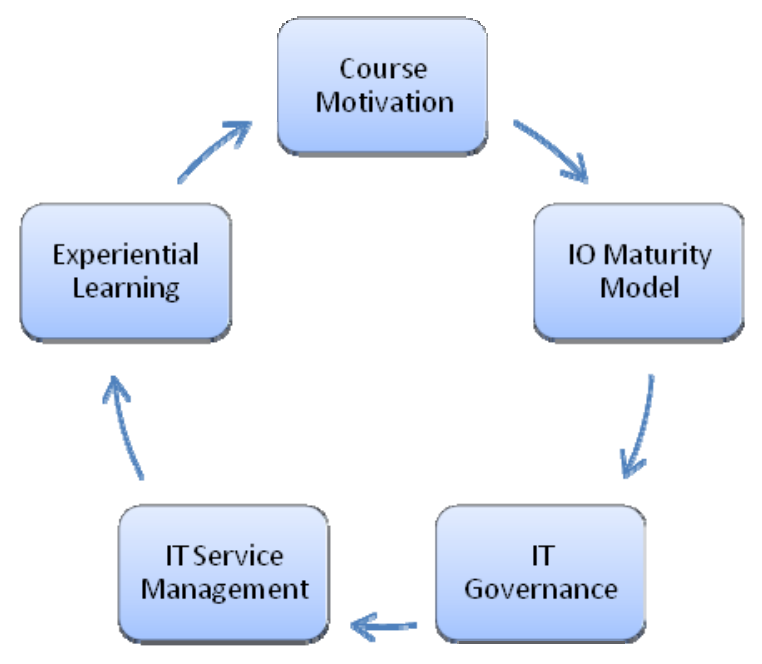

Figure 2. IT in Business High-Level Course Map

Table 1 provides a representative 15 -week course schedule identifying class topics and reading assignments. Note however, the authors continue to revise the course schedule and assigned readings. 
Information Orientation, IT Governance, and IT Service Management

Table 1. Representative 15-week course schedule

\begin{tabular}{|c|c|c|}
\hline Module & Topic & Readings \\
\hline Week 01 & Course Overview/ & $\begin{array}{l}\text { Search for Technology Panacea (Robinson, 1992); } 16 \\
\text { IT Failures (Krigsman, 2008) Netflix debacle (Stone, } \\
\text { 2008) }\end{array}$ \\
\hline Week 02 & $\begin{array}{l}\text { Is IT really strategic and do } \\
\text { you care? }\end{array}$ & $\begin{array}{l}\text { IT doesn't matters (Carr, 2003); Response to Carr (J. S. } \\
\text { Brown \& Hagel, 2003); IT Strategy Myths (Senn, } \\
\text { 1992) }\end{array}$ \\
\hline Week 03 & $\begin{array}{l}\text { Information Orientation } \\
\text { (IO) and introduction to IT } \\
\text { management frameworks }\end{array}$ & $\begin{array}{l}\text { Right mind-set for managing IT (Bensaou \& Earl, } \\
\text { 1998); Info Orientation (Marchand, Kettinger, \& } \\
\text { Rollins, 2000); IT Governance/IT Management Differ- } \\
\text { ences (Beachboard \& Aytes, 2011a) }\end{array}$ \\
\hline Week 04 & $\begin{array}{l}\text { IT Practices: IT-enabled } \\
\text { applications in a business } \\
\text { environment. }\end{array}$ & $\begin{array}{l}\text { Information: Let's get it right (McFarlan, 2004); Toy- } \\
\text { ota Business Intelligence (CIO Insight) Six mini cases; } \\
\text { be prepared for class discussion/analysis }\end{array}$ \\
\hline Week 05 & $\begin{array}{l}\text { Knowledge management: } \\
\text { Is there such a thing? }\end{array}$ & $\begin{array}{l}\text { Marketing Knowledge (Byran, 2004) Work Systems } \\
\text { Chapter } 12 \text { (Alter, 2006) }\end{array}$ \\
\hline Week 06 & $\begin{array}{l}\text { Business implication of } \\
\text { information lifecycle }\end{array}$ & $\begin{array}{l}\text { Information Lifecycle Management (Reiner, Press, } \\
\text { Lenaghan, Barta, \& Urmston, 2004) and re-review the } \\
\text { "getting information right article." }\end{array}$ \\
\hline Week 07 & $\begin{array}{l}\text { Information behavior and } \\
\text { Values }\end{array}$ & $\begin{array}{l}\text { Decision Models (Huber, 1981); Information as Sym- } \\
\text { bol (Feldman \& March, 1981) }\end{array}$ \\
\hline Week 08 & $\begin{array}{l}\text { Information behavior and } \\
\text { Values }\end{array}$ & $\begin{array}{l}\text { Info Distortion (Larsen \& King, 1996); Executive De- } \\
\text { lusions (Lovallo \& Kahneman, 2003) }\end{array}$ \\
\hline Week 09 & $\begin{array}{l}\text { IT Governance/IT Man- } \\
\text { agement }\end{array}$ & $\begin{array}{l}\text { Review IT governance/IT management difference essay } \\
\text { and read Implementing IT governance (Beachboard \& } \\
\text { Aytes, 2011c) }\end{array}$ \\
\hline Week 10 & ITSM Lifecycle Overview & $\begin{array}{l}\text { Introduction to ITIL }{ }^{\circledR} \text { v } 3 \text { (Cartlidge, Hanna, Rudd, } \\
\text { Macfarlane, Windebank, \& Rance, 2007) }\end{array}$ \\
\hline Week 11 & $\begin{array}{l}\text { Service design and the } \\
\text { work systems approach }\end{array}$ & $\begin{array}{l}\text { Work System Method - Chapters 2, 3, } 4 \text { and } 5 \text { (Alter, } \\
\text { 2006) }\end{array}$ \\
\hline Week 12 & $\begin{array}{l}\text { Service Level Management } \\
\text { and continuous service im- } \\
\text { provement }\end{array}$ & $\begin{array}{l}\text { Enterprise-level IT service management: service de- } \\
\text { sign, service transition and service operations (Beach- } \\
\text { board \& Aytes, 2011b) }\end{array}$ \\
\hline Week 13 & $\begin{array}{l}\text { Theory meets reality: Case } \\
\text { Presentations/discussion }\end{array}$ & None \\
\hline Week 14 & $\begin{array}{l}\text { Theory meets reality: Case } \\
\text { Presentations/discussion }\end{array}$ & None \\
\hline Week 15 & $\begin{array}{l}\text { Closed week; Individual } \\
\text { and Business Ethics; Class } \\
\text { wrap-up }\end{array}$ & IS ethical concerns (Smith, 2004) \\
\hline
\end{tabular}

\section{Motivating Students}

We do not claim a high degree of originality in using the introductory portion of the course to try to convince students that the content to be provided during the course is relevant and important. We do, however, allocate two and one half weeks and nine reading assignments to this effort. Our pitch is fairly straightforward. First and foremost we emphasize that we are offering a busi- 
ness course not an IT course: we will not be teaching about LANs and WANs, servers and storage, or applications development. It is not that we find such content useless. Our experience is that given that many of our students do not see the relevance of such content, their engagement with and retention of such material is poor.

Secondly, we advise that our intent is not to act simply as IT missionaries. Our interest is in the delivery of business value. If information technology helps deliver value, then great. If not, it should be avoided. On the first night of class we assign and analyze a short article, "The Search for a Technological Panacea" (Robinson, 1992) to illustrate the potential misuse of technology. This in-class exercise helps our students engage with the course content and introduces them to the type of critical thinking we encourage them to use in evaluating all assigned readings and class lectures. Additionally, we describe a variety of dramatic IT failures, ranging from the IRS's costly modernization effort to service failures at Netflix, Hershey and JetBlue (Daniel, Nash, \& Wailgum, 2008; Krigsman, 2008; Stone, 2008). We allude to the fact that a significant part of the problem with IT management lies in the apparent difficulties IT professionals and general business professionals have in effectively working with each other. We accept that IT professionals certainly must improve their working relationships with the business community, but argue that business professionals bear that responsibility as well.

Finally, we offer the argument that, while perhaps not always strategic, information technology is very important for the successful functioning of virtually all modern enterprises. Like several instructors we know, we analyze Nicholas Carr's (2003) infamous article, "IT Doesn't Matter", as well as one of the published responses (J. S. Brown \& Hagel, 2003). Our purpose is not to take a firm position one way or the other with respect to information technology's strategic value. We also discuss Senn's (1992) article on IT strategy myths offering a slightly different perspective on the Carr argument. However, we ultimately advocate that for most modern enterprises, information technology is important whether or not one wishes to label it strategic.

Consistent with our desire to produce affective as well as cognitive changes in our students, we wrap up the introductory section with Bensaou and Earl's (1998) article comparing the mindset of US and Japanese corporate managers regarding information technology. The article ties nicely back into the Robinson article by noting that US managers appear to be more enamored with technology than their Japanese counterparts and providing an opportunity for students to critically examine their attitudes toward information technology and its potential uses in the modern enterprise.

\section{Information Orientation as a Predictor of Business Performance}

We believe the Information Orientation (IO) Maturity model (see Figure 3) provides the most comprehensive framework describing what an enterprise needs to do well to effectively employ information and technology in support of its goals and objectives (Marchand et al., 2001).

The IO Model was developed by a team of researchers from the Institute of Management Development. The IO model is generally consistent with concepts and frameworks referenced in scholarly and prescriptive IT management literature (Boynton, Zmud, \& Jacobs, 1994; Broadbent \& Weill, 1997; C. V. Brown, 1997; C. V. Brown \& Magill, 1994; Ein-Dor \& Segev, 1982; Feeny \& Willcocks, 1998; King, 1983; King \& Kraemer, 1985; Rockart, Earl, \& Ross, 1996; Ross, Beath, \& Goodhue, 1996; Sambamurthy \& Zmud, 1999; Tavakolian, 1989; Weill \& Ross, 2004; Zmud, 1982, 1984). 


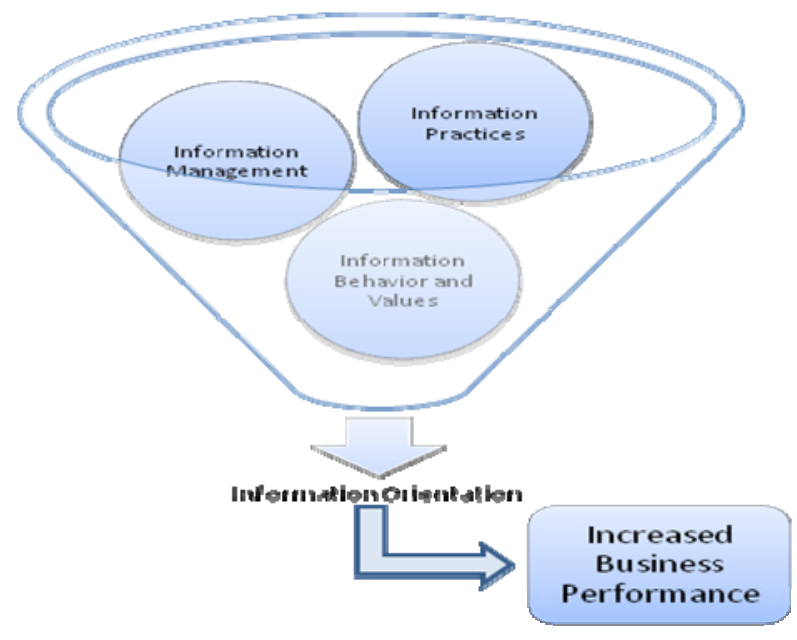

Figure 3. The Information Orientation Maturity Model

The model is particularly notable in its inclusion of insights derived from three disparate streams of IT management research. As described by its formulators, previous IT management work can be categorized "under three broad schools of management thinking and practice: (1) the Behavior and Control School, (2) the Information Management School, and (3) the Information Technology or IT School" (Marchand et al., 2001, p. 4). Broadly conceptualized, the Information Management School emphasizes lifecycle management of information as an organizational resource; the Behavior and Control School emphasizes the importance of individual and organizational behaviors and values influencing the use of information in an organizational context. The IT School focuses primarily on the identification and evaluation of effective IT management practices related to the automation of organizational tasks and managerial decision-making.

While recognizing the significant contributions made to the advancement of IT management thinking, the authors concluded that "each school also demonstrates key weaknesses that make the understanding and integration of the three information capabilities difficult and their links to business performance elusive" (Marchand et al., 2001, p. 4). What makes the model uniquely valuable for application as a pedagogical tool is the linking of these three schools of thought together and the model's explicit recognition of their combined effect on business performance. In essence, the IO model posits that organizations demonstrating higher levels of information orientation maturity will achieve higher levels of organizational performance. Importantly, the researchers found that achieving success required performance in all three domains: information technology practices (ITP), information management practices (IMP), and information behavior and values (IBV). Poor performance in any single domain is likely to undermine even high performance in the other two domains. The following sections briefly describe our approach to addressing each IO domain.

\section{Presentation of IT practices (ITP)}

As do many instructors, we rely primarily on case analyses to illustrate a variety of ways that IT can be employed. Our purpose is to continue to motivate our students and introduce them to the variety of ways in which information and technology can be employed to support business objectives. In addition to describing the specific categories of IT practices represented in the IO model, we introduce several frameworks for categorizing IT services. These include:

- McFarlan's (1984) application portfolio framework for evaluating IT services based on industry impact: strategic, turnaround, factory and support. 
- Gorry and Scott Morton's (1971) IT practices capability framework - as adopted in the IO model: IT for management support, IT for innovation support, IT for business process support, and IT for operational support.

- Schein's (1992) categories of strategic IT vision as adapted by Armstrong and Sambamurthy (1999): IT to automate, IT to informate up, IT to informate down and IT to transform.

We ask our students to analyze a number of short cases (often produced by IT vendors or drawn from the trade press rather than lengthier pedagogical cases) in terms of these conceptual frameworks. We ask students to see if they can identify IT services that do not appear to fit in any of the frameworks, and we ask students to assess whether discrete services support multiple purposes: i.e., do they fit nicely within more than one category or conceptual scheme? We have students consider how the IT service as described in the case might be leveraged to support more than the purposes identified in the various frameworks. While students often find the presentation of the frameworks to be rather dry, we have received favorable comments regarding the perceived value of in-class discussions resulting from the application of these frameworks to multiple cases.

\section{Presentation of information management practices (IMP)}

Information management, sometimes referred to as information resource management (IRM) started to really gain traction in the mid- 1970s, albeit primarily in the public sector. "The first principle of IRM was that information management needed to better balance the concerns of introducing new technologies and media with the treatment of information as a key resource (Marchand et al., 2001, p. 29), and "the second principle of IRM required managers to deal with information not just as a set of objects or artifacts such as data or files, but also as a process that extended from information's identification (sensing), collection, and organization through its processing, use and maintenance (p.30). For a variety of reasons, the term IRM has largely fallen out of favor, even though the problems it was intended to address are more salient today.

We take a two-pronged approach to addressing this area discussing (1) the information management lifecycle and (2) knowledge management. We typically expand on the information lifecycle steps incorporated in the IO mode. We were pleased to find a conference paper written by EMC storage engineers providing concrete methods for classifying "information based on its business value" and supporting the development of value-based IM policies (Reiner et al., 2004).

We also address briefly the knowledge management domain, assigning positive as well as cautionary articles regarding the subject. For example, we assign the report by a McKinsey analyst "Making a Market in Knowledge" which approaches the subject positively but in a critical manner (Bryan, 2004).

\section{Presentation of information behavior and values (IBV)}

In terms of translating a theoretical understanding into practical action, perhaps no domain is more difficult than information behaviors and values. Relying heavily on Kahneman and Tversky's on decision-making heuristics and cognitive biases (see Kahneman, Slovic, \& Tversky, 1982), as well as the more recent behavioral economics research (Ariely, 2008), we introduce our students to common information-processing and decision-making behaviors that tend to depart from the norms associated with rational decision-making. We establish the business context for the subject by assigning several classic readings, such as Huber's (1981) description of rational, political, garbage can, and program models of decision-making and Feldman and March's (1981) discussion of the symbolic use of information in organizations. We also assign more recent arti- 
cles addressing systematic distortion of or inattention to relevant information (Larson \& King, 1996; Lovallo \& Kahneman, 2003).

Students often ask how they should fix the problem when they observe non-rational forms of decision-making and information use at higher levels of management. We certainly have not cracked the problem of how to avoid these human tendencies beyond the notion that awareness of the problem might prove prophylactic to some extent. However, some authors have argued that awareness may not be enough (Carroll \& Mui, 2008). We do introduce prescriptions, e.g., the use of devil's advocates (Carroll \& Mui, 2008) or "taking the outside view" (Lovallo \& Kahneman, 2003), even though we recognize that there are significant limitations to what these recommendations can accomplish.

\section{IO wrap-up}

At a macro-level, the IO model presents students with an overarching conceptualization of the things that an enterprise needs to do well to successfully employ information and information technology. While we are able to introduce some specific information concerning the types of thinking and actions required to raise an enterprise's IO, the model itself does not provide much explicit implementation guidance. Having set the direction for the enterprise, we begin to peel the onion and delve more deeply into specific actions managers can take to raise their enterprise IOs.

\section{IT Governance: Establishing Direction and Boundaries for Action}

As introduced above, we have chosen to partition the overarching IT management discipline into three domains: executive-level IT governance, enterprise IT management/governance, and functional IT management/governance. In our class, we limit discussion of IT governance to the range of IT management activities that require substantive executive- or board-level engagement. Using a shipping metaphor, governance might be viewed as the business owners' selection of cargo, ports of origination and destination, and establishment of the resource levels to be allocated for accomplishing the task. The business managers are allowed, within set parameters, to select the ship and crew, manage the crew, and navigate and maintain the ship. The business owners may veto management actions based on their evaluation of quality and risks associated with the management-recommended strategy. IT governance then consists of board- or executive-level development or approval of the enterprise's strategy for how information and technology are employed in support of accomplishing enterprise goals and maintaining a level of oversight required to ensure that IT management actions remain consistent with the identified strategy.

Reflecting what we believe to be a reasonable interpretation of Weill and Ross's (2004) and Ross, Weill, and Robertson's (2006) work on IT governance and the development of enterprise architectures, we have conceptualized IT governance as consisting of three primary activities: specification of the enterprise IT management structure, development of a high-level enterprise strategic IT vision, and determination of IT investment levels and priorities as depicted in Figure 4. 


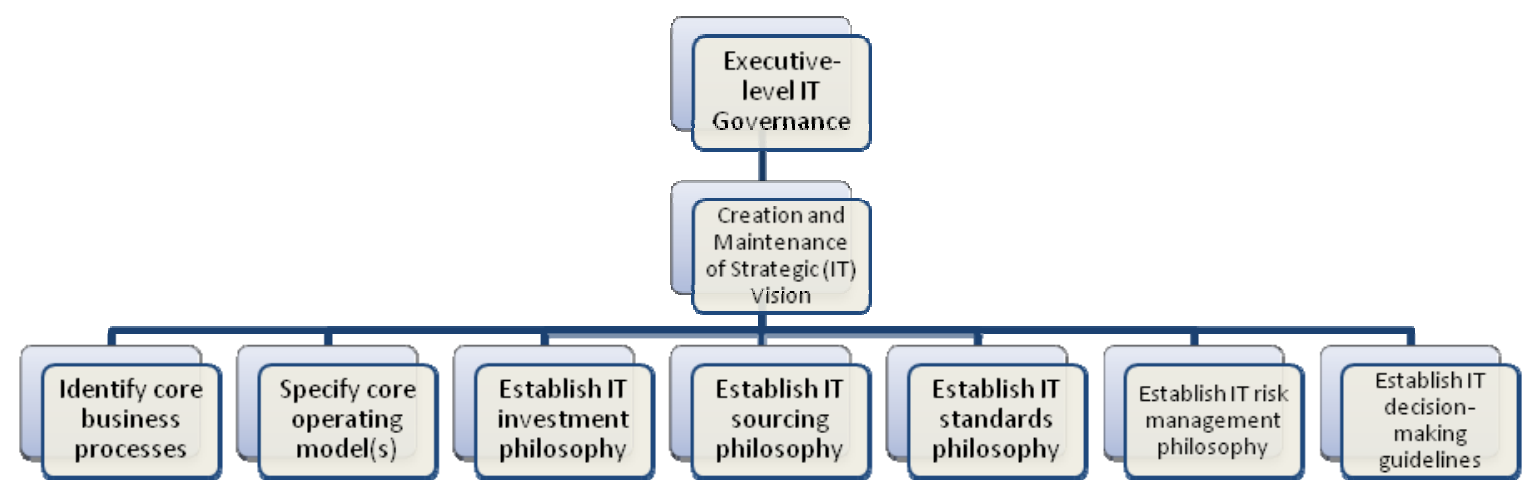

Figure 4. IT Governance Reformulated

Currently, we employ self-authored working papers that synthesize work of prominent authors writing on IT governance and the development of enterprise information architectures (Beachboard \& Aytes, 2011a, 2011c). In particular, we draw on elements of Weill and Broadbent's (1998) research on IT infrastructures, Weill and Ross's (2004) research on IT governance and the later Ross et al. (2006) elaboration of recommended enterprise architecture development practices.

Our primary emphasis is on helping our students understand the need for executive involvement in establishing the enterprise's fundamental IT principles or philosophy. We elaborate upon Ross et al.'s (2006) prescriptions regarding the selection of the enterprise's operating model (or models) and the influence the operating model should have on the development of the IT integration and standardization policies. We specifically relate the IT principles back to the IO dimensions, particularly with respect to how executives might use policies to facilitate improvements in the enterprise's information behavior and values. Furthermore, we address:

- IT governance mechanisms that enterprises use to oversee the IT function (e.g., establishment of executive-level IT steering committees)

- Management of IT investments (e.g., investment analysis and prioritization and chargeback).

- Laws (e.g., Sarbanes-Oxley Act, Gramm, Leach Bliley Act) and industry standards (Payment Card Industry security standards), and legal, financial and ethical risks associated with non-compliance

As many of our MBA students have extensive work experience, discussions concerning the strengths and weaknesses of executive driven-policies can be quite lively as well as informative.

We wrap up our discussion of executive-level governance by asking our students to explicitly consider what effective IT governance accomplishes and what IT governance leaves unaccomplished. Executive-level IT governance establishes parameters for formulating and executing the enterprise IT strategy and the means for controlling and evaluating the IT strategy as executed. We suggest that evolving IT service management practices, particularly as documented by ITIL $\mathbb{}$ v.3 and ISO 20000 (which is the International Standard for certifying service provider organizations in IT service management) represent another important layer of know-what/know-how for creating and executing the enterprise IT strategy. 


\section{IT Service Management (ITSM): Converting Governance to Action}

IT Infrastructure Library (ITIL) ${ }^{\circledR}$ v.3's presents IT Service Management (ITSM) concepts in terms of IT service lifecycle and identifies the IT management processes needed to align IT services with business needs - particularly in the volumes on service strategy (Iqbal \& Nieves, 2007) and service design (Lloyd \& Rudd, 2007). The ITIL $\AA$ service strategy volume overlaps considerably with the IT governance literature and much of the traditional IT strategy literature, but the adoption of ITIL ${ }^{\circledR}$ content has two advantages over the generic IT strategy literature. From a marketing perspective, there is a buzz associated with ITSM and ITIL ${ }^{\circledR}$, as more U.S. and international enterprises adopt ITSM-related practices (Dubie, 2008). More importantly, ITIL ${ }^{\circledR}$ describes a comprehensive and disciplined approach for developing an enterprise's IT service strategy and designing and delivering IT services that are aligned with the enterprise's needs.

The core insights underlying virtually all ITSM frameworks are (1) emphasizing the design of IT services rather than the specification of business applications and technology, and (2) making explicit the linkage between the IT services and the business processes they are intended to support. ITSM recognizes that business value resides in the business processes and IT service value is assessed in terms of its contribution to the performance of business processes. IT professionals and business managers generally have understood that IT investments are intended to support business needs and have long conducted cost-benefit analyses to justify making such investments. The benefit derived from the adoption of an IT service orientation is that it helps make the relationship between IT investment and business value more explicit and helps the IT activity maintain its focus on the value-creating aspects of the services it provides to the enterprise. Perhaps just as importantly, ITSM offers a vocabulary more easily understood by non-IT management, thus helping to improve communication between IT and the activities it supports.

It is important to understand what we mean by IT services. ${ }^{1}$ IT services are a set of related functions provided by IT systems in support of the business and perceived by the customer and user as a coherent and self-contained entity. IT services have to be looked at from an end-to-end user perspective extending across multiple technology silos. ISO 20000 and the ITIL $₫$ body of knowledge describe a range of business-oriented processes that should be in place to provide quality IT services, aligned with organizational needs. The latest version of ITIL ${ }$, Version 3, now follows a lifecycle approach (Figure 5), which includes five core publications in the new ITIL library:

1. Service Strategy addresses the need to integrate business and IT so that organizations get the most out of IT services. It ensures that IT service strategies are linked to business plans and strategies.

2. Service Design provides the guidance and maintenance of IT architectures, policies, and documents needed to meet current and future business requirements. It is through service design that innovative solutions and processes are developed to best support the business.

3. Service Transition focuses on transforming an organization into a service-based culture through long-term change management, release and deployment management, and service asset and configuration-management processes. Service transition is a critical stage in the lifecycle to manage and mitigate risks effectively. Knowledge management concepts are also introduced.

4. Service Operations focuses on the day-to-day operations of managing the IT organization. It emphasizes service delivery and control process activities that effectively manage and stabilize services on a day-to-day basis.

\footnotetext{
${ }^{1}$ An overview of ITIL is available in Beachboard, et al. (2007).
} 
5. Continual Service Improvement has always been a strong part of ITIL and continues to be in ITIL 3.0. It supports the importance of following a quality approach to improving service and embraces the importance of standards, especially ISO 20000.

Thus, the global popularity of ITIL $®$ as a de facto standard of good practice is founded on several key drivers: risk management, financial value return, and operational discipline.

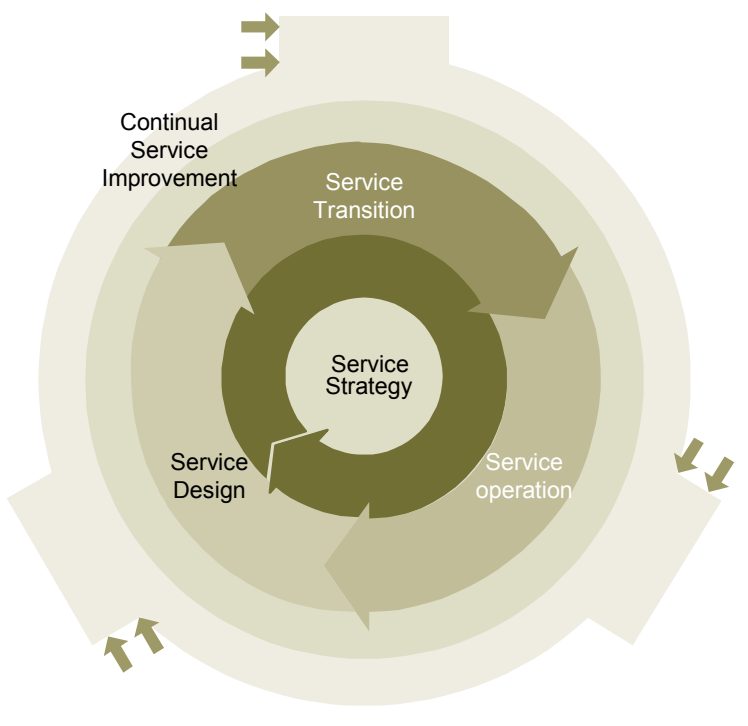

Figure 5. The ITIL Core (adapted from Iqbal \& Nieves, 2007, p. 8)

The development and maintenance of an IT service portfolio, IT services catalog, and associated service level agreements are well- defined tasks that students readily grasp. Furthermore, an instructor is able to find current examples in the trade literature that demonstrate that, done correctly, the adoption of these processes can deliver real value.

The approach we currently use is to assign and briefly discuss the introductory overview of ITIL ${ }^{\circledR}$ v.3 (available free from itSMF). We then delve more deeply into the service design process by combining several chapters from Alter's textbook introducing the work-systems method (Alter, 2006) and several vendor whitepapers discussing service-level adoption issues and methods. The incorporation of the work-systems method in this module may seem to be something of a stretch. However, we believe Alter has provided a rigorous and practical approach for analyzing the relationship between business processes and supporting IT services that, while adopting a slightly different vocabulary, aligns quite well with the service design practices recommended in ITIL $®$. The ITIL $®$ complements the work-system methods by providing mechanisms to more explicitly document service quality requirements (confidentiality, integrity, availability, reliability, and performance) and tracing the implications of identified service level requirements on the design of the supporting IT infrastructure and service management process. We are early in our adoption of this content and remain on the lookout for additional suitable readings.

We relate our presentation of the ITIL ${ }^{\circledR}$ framework back to our three-domain conceptualization of IT management (Figure 1). Many of the activities described in the service-strategy and service-design literature clearly require the active participation of IT and non-IT management. This raises questions concerning responsibility and authority. Some argue that true responsibility, or accountability, cannot be split. However, the IT staff, which would commonly be held responsible for creation of service catalogs and service-level agreements, is generally not in a position to dictate or manage the quality of user participation in these efforts. 
Information Orientation, IT Governance, and IT Service Management

We wrap up our ITSM module by re-addressing issues raised in the introductory module of the course pertaining to the importance of information technology and the influence of management attitudes and organization on the effectiveness of IT initiatives. We ask our working students to assess whether they think IT users in their organizations would be willing to participate in the type of service design actions presented in the ITSM module and to explain why or why not. We ask all of our students to consider whether users "should" be willing to participate in these efforts and consider the question of whether implementing the recommended practices would result in tangible benefits for the enterprise.

\section{Synthesizing Content via Experiential Learning}

We believe there is only so much that can be accomplished through assigned readings, lectures, and class discussion, and that experiential learning substantially assists our students in integrating the concepts introduced in this class. To a great extent, the course content squares with the students' common-sense understanding of what should be done to effectively manage information technology. But as Pfeffer and Sutton (2000, p. 54) have argued, too many managers (and students) tend to confuse "ease of understanding with ease of implementation." Developing a tacit understanding or real know-how often requires experiential learning (Dewey, 1938/1997; Kolb, 1984; Pfeffer \& Sutton, 2000).

To that end, we assign a semester-long project in which student teams consult with area businesses (or not-for-profit organizations). The assignment calls for the structured application of one of the conceptual frameworks introduced in the course. We have had students administer enterprise IQ's IO maturity assessment instrument, but we are exploring the use of other assessment tools as well. The students administer structured surveys, perform open-ended interviews, conduct participant observation, and analyze their findings, providing oral and written reports to the client and to the class (Aytes \& Beachboard, 2007). While arranging these experiences can prove challenging, particularly in lightly populated geographic areas, student and business responses to these projects have been generally favorable.

We treat this assignment as a course module rather than a simple group assignment because we have learned that, to derive maximum benefit from the effort, we need to allow sufficient in-class time to present and discuss project results. We find that students not only benefit from their own efforts but vicariously through the sharing and comparing of experiences with other groups. Dedicating time for these presentations does come at a cost. There certainly is other content that could be incorporated into the course. So far, the time dedicated to supporting this assignment appears to be well- warranted.

\section{Initial Results}

Given an evolving course design, the inevitable differences among classes in terms of student enrollments and class cultures, and a relatively small number of class offerings, we cannot produce a scientifically rigorous evaluation of the course design. Nonetheless, course evaluations, informal surveys, and direct feedback from students do provide evidence that student engagement and learning is improving with the introduction of our course redesign. Most notably, we have observed significant improvements in student attitudes toward the material.

In our evaluation process, we ask students to assess their attitudes toward the course at the beginning and end of the semester. Students have consistently communicated an unfavorable attitude toward the class before taking it. On a four-point scale, where a one reflects a negative opinion of the course and a four reflects a positive opinion, the pre-course assessments have consistently ranged between 2.5 and 2.7. Since adopting the new approach, we have seen end-of-course attitudes ranging from about 3.1 to 3.5, reflecting positive changes in aggregate student attitudes. 
The following comments were received during the course evaluations where students are asked to identify what they liked about the course:

- [Class] forced me to consider more of the IT side of things without having to learn the $1 \mathrm{~s}$ and $0 \mathrm{~s}$

- Concept that every level of management needs to participate in IT management

- Work system method

- Lot of information applicable to MBAs

- Gained new perspective concerning work systems

- Course taught from business standpoint

- Different look at IT - liked the information centric view and approach

- Liked IO and project

- Understanding that IT is a business function - IT is not isolated

- Course applicable to business not just technical side of IT

- Liked how it was a business class and not an IT class

- Readings were useful and created interesting insight; the project was useful and informative

- Business not IT class

Of course, not all comments received are uniformly positive. We have received a small number of comments indicating that we should spend more time focusing just on the work systems method or on the IO Maturity model. But then we almost always receive a few comments suggesting that the work systems method or IO Maturity model is a complete waste of time and should be dropped from the course. We tend to discount these relatively few, seriously negative comments, but do seek to improve content selection and delivery to minimize such resistance.

For example, we receive more comments than we would like where students express discontent because they do not see how the course content can be applied in their work environments. More recently, we have been identifying more traditional pedagogical cases to reinforce the application of core concepts. Thus, in our most recent course offering we have used teaching cases such as, IT governance at Oxford Industries (Wybo \& Bernier, 2008) to illustrate the concept of IT governance and the Security breach at TJX (Haggerty \& Chandrasekhar, 2008) to demonstrate the potential for serious financial losses resulting from IT service failure.

Our results are perhaps best summarized by the findings from pre- and post-course surveys of our most recent course offering. In response to the statement, "I understand the role that information systems play in modern enterprises" student self- appraisals rose from 3.79 (pre) to 4.30 (post), with a one indicating little or no confidence and a five indicating a very high degree of confidence. However, when asked to evaluate the statement, "I am capable of participating in planning the use of information technology in an enterprise," students were less sanguine in their assessments, averaging 3.77 on the pre-course survey and only 4.07 on the post-course survey. The results are statistically significant but indicate less dramatic improvement than we would like to see.

\section{Conclusions}

In terms of cognitive content, our course varies relatively little from more traditional core MBA IS courses. The primary factors that we think distinguish our approach are:

1. The emphasis placed on mid-management problem-solving, decision-making and process improvements relative to the strategy orientation found in many IS management courses. 
Information Orientation, IT Governance, and IT Service Management

2. The attempt to [more] clearly delineate and explain IT management roles and responsibilities of general business managers relative to the set of IT management responsibilities of IT managers and professionals

3. The emphasis placed on helping our students understand the significance of individual and organizational information behavior and values relative to the effective management and use of information and technology in the enterprise

4. Our interest on affective learning, i.e., cultivating an attitude among our students to actively engage in the management of information and technology in their organizations.

We believe the last point to be the most critical and the most challenging. By the time they get to graduate school, most students have become masters at doing what must be done to earn the grades they wish to earn and managing to shed much of what was learned in a matter of weeks after completing their courses. Changing attitudes is not easy. We cannot claim complete success and doubt complete success is possible. Certainly, some percentage of students will continue to believe that "IT is not my job!" We do hope students understand that the preceding statement does not reflect opposition to the argument we make. Rather, we teach about sharing the responsibility for the effective management and use of information and technology in the enterprise. Admittedly, some students leave the course with their doubts about our proposition intact.

Thus, our course remains a work in progress. Like most instructors, we continue to wrestle with issues concerning which content to include or exclude and how to select the most effective reading and writing assignments. We share our approach because we believe it offers a viable means to address concerns expressed via the ISWorld Listserv and reflected in published commentary about the inclusion of IT-related courses in the MBA core. We believe that, with the continuing refinements to the course, particularly the introduction to the work systems method and incorporation of ITIL $\AA$, we will see further improvements.

We are careful not to be perceived simply as IT cheerleaders. We emphasize and re-emphasize that information and technology do not represent silver bullets; they do not offer solutions to all business problems. We do provide plenty of evidence that information technology is critically important to most modern enterprises and that it behooves general business managers to fully participate in the development and management of IT solutions.

\section{References}

Alter, S. (2006). The work systems method: Connecting people, processes, and IT for business results. Larkspur, CA: Work Systems Press.

Ariely, D. (2008). Predictably irrational: The hidden forces that shape our decisions. New York, NY: HarperCollins.

Armstrong, C. P., \& Sambamurthy, V. (1999). Information technology assimilation in firms: The influence of senior leadership and it infrastructures. Information Systems Research, 10(4), 304-327.

Avison, D. (2003). Information systems in the MBA curriculum: An international perspective. Communications of the AIS, 11, 117-127.

Aytes, K., \& Beachboard, J. (2007). Using the Information Orientation Maturity Model to increase the effectiveness of the core MBA IS course. Journal of Information Technology Education, 6, 371-385. Retrieved from http://www.jite.org/documents/Vol6/JITEv6p371-385Aytes262.pdf

Beachboard, J. C., \& Aytes, K. (2011a). Conceptualizing IT governance. ISU working paper. (Manuscript in preparation).

Beachboard, J. C., \& Aytes, K. (2011b). Enterprise-level IT service management: Service design, service transition and service operations. ISU Working paper. (Manuscript in preparation). 
Beachboard, J. C., \& Aytes, K. (2011c). Implementing IT governance. ISU working paper. (Manuscript in preparation).

Beachboard, J., Conger, S., Galup, S. D., Hernandez, A., Probst, J., \& Venkataramen, R. (2007). AMCIS 2007 panel on IT service management: IT service management in the IS curriculum. Communications of the AIS, 20, 555-566.

Bensaou, M., \& Earl, M. (1998). The right mind-set for managing information technology: Japanese and American methods. Harvard Business Review, 76(5), 119-120.

Boynton, A. C., Zmud, R. W., \& Jacobs, G. C. (1994). The influence of IT management practice on IT use in large organizations. MIS Quarterly, 18(3), 299-318.

Broadbent, M., \& Weill. P. (1997). Management by maxim: How business and IT managers can create IT Infrastructures. Sloan Management Review, 38(3), 77-92.

Brown, C. V. (1997). Examining the emergence of hybrid IS governance solutions: Evidence from a single case site. Information Systems Research, 8(1), 69-94.

Brown, C. V., \& Magill, S. L. (1994). Alignment of the IS functions within the enterprise: Toward a model of antecedents. MIS Quarterly, 18(4), 371-394.

Brown, J. S., \& Hagel, J., III. (2003). Does IT matter? Sloan Management Review, 81(7), 109-112.

Bryan, L. L. (2004). Making a market in knowledge. The McKinsey Quarterly. Retrieved Dec. 12, 2008, from http://www.mckinseyquarterly.com/Making_a market_in_knowledge_1441

Carr, N. G. (2003). IT doesn't matter. Harvard Business Review, 81(5), 41-49.

Carroll, P., \& Mui, C. (2008). Billion dollar lessons: What you can learn from the most inexcusable business failures of the last 25 years. New York, NY: Portfolio.

Cartlidge, A., Hanna, A., Rudd, C., Macfarlane, I., Windebank, J., \& Rance, S. (2007). An Introductory Overview of ITIL(R) v.3 (ItSMF). UK Chapter of the ITSMF.

Daniel, D., Nash, K. S., \& Wailgum, T. (2008, 16 November). How IT failures wreck holidays, special occasions for many companies. CIO.Com. Retrieved from http://www.cio.com/article/155051/How_IT_Failures_Wreck_Holidays_Special_Occasions_for_Many Companies

Dewey, J. (1997). Experience and education. New York, NY: First Touchstone Edition. (Original work published in 1938).

Dubie, D. (2008, February 29). ITIL adoption increases in U.S., proficiency still lacking. NetworkWorld. Retrieved from http://www.networkworld.com/news/2008/022908-itil-adoption.html

Ein-Dor, P., \& Segev, E. (1982). Organizational context and MIS structure: Some empirical evidence. MIS Quarterly, 6(3), 55-68.

Feeny, D. F., \& Willcocks, L. (1998). Core IS capabilities for exploiting information technology. Sloan Management Review, 39(3), 9-21.

Feldman, M. S., \& March, J. G. (1981). Information in organizations as signal and symbol. Administrative Science Quarterly, 26(2), 171-186.

Gorry, A. G., \& Scott Morton, M. S. (1971). A framework for management information systems. Sloan Management Review, 13(1), 55-70.

Haggerty, N, \& Chandrasekhar, R. (2008). Security breach at TJX. London, Ontario, Canada: Richard Ivey School of Business. [Case 908E03].

Huber, G. P. (1981). The nature of organizational decision making and the design of decision support systems. MIS Quarterly, 5(2), 1-10.

Iqbal, M., \& Nieves, M. (2007). ITIL: Service strategy. United Kingdom: OGC. 
Information Orientation, IT Governance, and IT Service Management

IT Governance Institute. (2009). Cobit 4.1 executive summary framework. Retrieved Aug. 9, 2009 from http://www.isaca.org/AMTemplate.cfm?Section=Downloads\&Template=/ContentManagement/Conten tDisplay.cfm\&ContentID $=34172$

Ives, B., Valacich, J., Watson, R., Zmud, R., Alavi, M., Baskerville, R., ... . Whinston, A. B. (2002). What every business student needs to know about information systems. Communications of the AIS, 9, 467477.

Kahneman, D., Slovic, P., \& Tversky, A. (1982). Judgment under uncertainty: Heuristics and biases. Cambridge, UK: Cambridge University Press.

King, J. L. (1983). Centralized versus decentralized computing: Organizational considerations and management options. Computing Surveys, 15(4), 319-349.

King, J. L., \& Kraemer, K. L. (1985). The dynamics of computing. New York: Columbia University Press.

Kolb, D. A. (1984). Experiential learning: Experience as the source of learning and development. Englewood Cliffs, NJ: Prentice-Hall.

Krigsman, M. (2008, 10 November). Sixteen IT failures to remember. ZDNet.Com. Retrieved Dec. 102008 from http://blogs.zdnet.com/projectfailures/?p=1132

Larson, E. W., \& King, J. B. (1996). The systemic distortion of information: An ongoing challenge to management. Organizational Dynamics, 24(3), 49-61.

Lloyd, V., \& Rudd, C. (2007). ITIL: Service design. United Kingdom: OGC.

Lovallo, D., \& Kahneman, D. (2003). Delusions at the desktop: How optimism undermines executive decisions. Harvard Business Review, 81(7), 56-63.

Luftman, J. N. (2004). Managing the information technology resource: Leadership in the information age. Upper Saddle River, NJ: Pearson Prentice Hall.

Marchand, D. A., Kettinger, W. J., \& Rollins, J. O. (2000). Information orientation: Technology and the bottom line. Sloan Management Review, 41(4), 69-80.

Marchand, D. A., Kettinger, W. J., \& Rollins, J. O. (2001). Making the invisible visible. West Sussex, England: Wiley.

McFarlan, F. W. (1984). Information technology changes the way you compete. Harvard Business Review, 62(3), 98-103.

Peslak, A. R. (2005). Incorporating business processes and functions: Addressing the missing element in information systems education. Journal of Computer Information Systems, 45(4), 56-61.

Pfeffer, J., \& Sutton, R. (2000). The knowing doing gap: How smart companies turn knowledge into action. Boston, MA: Harvard.

Reich, B. H. (2000). Designing the IT course within an executive MBA. Communications of the AIS, 3, 122.

Reiner, D., Press, G., Lenaghan, M., Barta, D., \& Urmston, R. (2004). Information lifecycle management: The EMC perspective. In Proceedings of the 20th International Conference on Data Engineering (pp. 100-111). Boston, MA: IEEE.

Robinson, J. A. (1992). The search for the technological panacea. Information Systems Strategy: The Executive's Journal, 8(4), 28-30.

Rockart, J. F., Earl, M. J., \& Ross, J. W. (1996). Eight imperatives for the new IT organization. Sloan Management Review, 38(1), 43-55.

Ross, J. W., Beath, C. M., \& Goodhue, D. L. (1996). Develop long-term competitiveness through IT assets. Sloan Management Review, 38(1), 31-42.

Ross, J. W., Weill, P., \& Robertson, D. C. (2006). Enterprise architecture as strategy: Creating a foundation for business execution. Boston, MA: Harvard Business School Press. 
Sambamurthy, V., \& Zmud, R. W. (1999). Arrangements for information technology governance: A theory of multiple contingencies. MIS Quarterly, 23(2), 261-290.

Schein, E. H. (1992). The role of the CEO in the management of change: The case of information technology. In T. A. Kochan \& M. Useem (Eds.), Transforming organizations (pp. 80-96). Oxford: Oxford University Press.

Senn, J. A. (1992). The myths of strategic systems: What defines true competitive advantage. Information Systems Management, 9(3), 7-12.

Shore, B., \& Briggs, W. (2007). Competitive analysis of MIS in the MBA core: Are trends putting pressure on the MIS course? Journal of Information Systems Education, 18(1), 63-68.

Silver, M. S., Markus, M. L., \& Beath, C. M. (1995). The information technology interaction model: A foundation for the MBA core course. MIS Quarterly, 19(3), 361-390.

Smith, H. J. (2004). "But what is the right thing?" Ethics and information systems in the corporate domain. MIS Quarterly Executive, 33(2), 105-115.

Stone, B. (2008, 15 August). Lessons from Netflix's fail week. The New York Times. Retrieved from http://query.nytimes.com/gst/fullpage.html?res=9F02E4DC123CF93BA2575BC0A96E9C8B63

Tavakolian, H. (1989). Linking the information technology structure with organizational competitive strategy: A survey. MIS Quarterly, 13(3), 309-317.

Weill, P., \& Broadbent, M. (1998). Leveraging the new infrastructure: How market leaders capitalize on information technology. Boston, MA: Harvard Business School Press.

Weill, P., \& Ross, J. W. (2004). IT governance: How top performers manage IT decision rights for superior results. Boston, MA: Harvard Business School Press.

Wybo, M., \& Bernier, C. (2008). IT governance at Oxford Industries: Information architecture for financial data. International Journal of Case Management, 6(1), 1-14.

Zmud, R. W. (1982). Diffusion of modern software practices: Influence of centralization and formalization. Management Science 28, 1421-1431.

Zmud, R. W. (1984). An examination of "push-pull" theory applied to process innovation in knowledge work. Management Science 30, 727-38.

\section{Biographies}

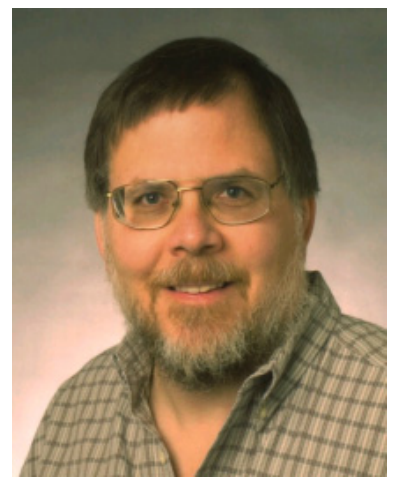

John C. Beachboard joined the Computer Information Systems faculty at Idaho State University in 2001. He completed the Ph.D. in Information Transfer and the M.S. in Information Resources Management at the School of Information Studies, Syracuse University. He holds an M.S. in Business Administration from Boston University and a B.S. in Public Administration from the University of Arizona. Dr. Beachboard has taught graduate courses in research methods, project management, and IT use in business, and undergraduate courses in IT management and systems architectures. He has held staff and management positions developing, implementing and operating information and telecommunications systems for the Department of Defense. He is keenly interested in the development, application and effectiveness of information technology management policies in the private and public sectors. 


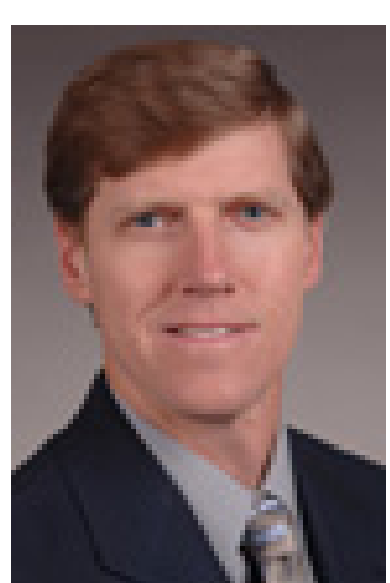

Kregg Aytes has been a member of the Computer Information Systems faculty at Idaho State University since 1993. He completed his $\mathrm{Ph} . \mathrm{D}$. at the University of Arizona in that same year. Kregg teaches graduate and undergraduate courses in CIS, served as CIS Department Chair, and has been Associate Dean since 2008. His research interests include information security, collaborative technologies and social media use by entrepreneurs. He also has a strong love of teaching and is interested in the application of IS content and skills across the business school curriculum. 